\title{
The description of two new species of Chloromyxum from skates in the Argentine Sea reveals that a limited geographic host distribution causes phylogenetic lineage separation of myxozoans in Chondrichthyes
}

\author{
Delfina María Paula Cantatore ${ }^{1, *}$, Manuel Marcial Irigoitia ${ }^{1}$, Astrid Sibylle Holzer ${ }^{2}$, Pavla Bartošová-Sojková ${ }^{2}$,
} Hana Pecková ${ }^{2}$ Ivan Fiala ${ }^{2}$, and Juan Tomás Timi ${ }^{1}$

${ }^{1}$ Laboratorio de Ictioparasitología, Instituto de Investigaciones Marinas y Costeras (IIMyC), Consejo Nacional de Investigaciones Científicas y Técnicas (CONICET), Universidad Nacional de Mar del Plata, Mar del Plata, Argentina

2 Institute of Parasitology, Biology Centre of the Czech Academy of Sciences, Branišovská 31, 37005 České Budějovice, Czech Republic

Received 12 April 2018, Accepted 13 August 2018, Published online 12 September 2018

\begin{abstract}
During a survey on the myxosporean fauna of Rajiformes from the Atlantic coast of Argentina, in waters off Buenos Aires Province $\left(34^{\circ}-42^{\circ} \mathrm{S} ; 53^{\circ}-62^{\circ} \mathrm{W}\right)$, the gall bladders of 217 specimens belonging to seven species of skates, representatives of two families, were examined. As a result, three species of Chloromyxum Mingazzini, 1890, namely C. atlantoraji n. sp., C. zearaji n. sp. and C. riorajum Azevedo, Casal, Garcia, Matos, Teles-Grilo and Matos, 2009 were found infecting three endemic host species, the spotback skate Atlantoraja castelnaui (Arhynchobatidae), the yellownose skate Zearaja chilensis (Rajidae) and the Rio skate Rioraja agassizii (Arhynchobatidae), respectively. These species were described based on myxospore morphology and morphometry characterization, as well as by providing their small subunit ribosomal DNA (SSU rDNA) sequences. The SSU rDNA-based phylogenetic analyses showed that these three species constituted a well-established monophyletic subclade within the marine Chloromyxum clade, while branches subtending the other Chloromyxum species were poorly resolved or unresolved, independently of the host taxonomic identities (Carchariniformes, Myliobatiformes, Orectolobiformes, Pristiophoriformes, Rajiformes, Squaliformes and Torpediniformes) and/or host geographic distribution (Atlantic coast of Portugal, Atlantic coast of the USA, Australian waters or Mediterranean Sea). The possible causes of these discrepancies are discussed, providing new insights into the phylogeny of the marine Chloromyxum clade.
\end{abstract}

Key words: Chloromyxum sp., SSU rDNA sequences, elasmobranchs, Atlantoraja castelnaui, Zearaja chilensis, Rioraja agassizii.

\begin{abstract}
Résumé - La description de deux nouvelles espèces de Chloromyxum à partir de raies de la mer d'Argentine révèle qu'une répartition géographique limitée des hôtes entraîne la séparation des lignées phylogénétiques des Myxozoaires chez les Chondrichtyens. Lors d'une étude de la faune des Myxozoaires des Rajiformes de la côte atlantique argentine, dans les eaux situées au large de la province de Buenos Aires $\left(34^{\circ}-42^{\circ} \mathrm{S} ; 53^{\circ}-62^{\circ} \mathrm{O}\right)$, les vésicules biliaires de 217 spécimens appartenant à sept espèces, représentants deux familles, ont été examinés. En conséquence, trois espèces de Chloromyxum Mingazzini, 1890, à savoir C. atlantoraji n. sp., C. zearaji n. sp. et C. riorajum Azevedo, Casal, Garcia, Matos, Teles-Grilo et Matos, 2009 ont été trouvées, infectant trois espèces hôtes endémiques, Atlantoraja castelnaui (Arhynchobatidae), Zearaja chilensis (Rajidae) et Rioraja agassizii (Arhynchobatidae), respectivement. Ces espèces sont décrites sur la base de la morphologie et de la morphométrie des myxospores, ainsi qu'en fournissant leurs petites séquences d'ADN ribosomal (SSU ADNr). Les analyses phylogénétiques basées sur l'ADNr SSU ont montré que ces trois espèces constituaient un sous-clade monophylétique bien établi dans le clade des Chloromyxum marins, tandis que les branches sous-jacentes aux autres espèces de Chloromyxum étaient mal ou non résolues, indépendamment des identités taxonomiques hôtes (Carchariniformes, Myliobatiformes, Orectolobiformes, Pristiophoriformes, Rajiformes, Squaliformes et Torpediniformes) et/ou de la répartition géographique de l'hôte (côte atlantique du Portugal, côte atlantique des États-Unis, eaux australiennes ou mer Méditerranée). Les causes possibles de ces divergences sont discutées, fournissant de nouvelles informations sur la phylogénie du clade des Chloromyxum marins.
\end{abstract}

\footnotetext{
*Corresponding author: cantator@mdp.edu.ar
} 


\section{Introduction}

Along the Southwestern Atlantic Shelf, south of $34^{\circ} \mathrm{S}, 106$ elasmobranch species have been reported among permanent and occasional inhabitants, two of which are holocephalans, 55 are sharks, and 49 are batoids [20, 22, 60, 62, 75]. Elasmobranch richness is heterogeneous across this region, mainly associated with a marked temperature gradient [45, 59, 63], with the presence of marine fronts [58] and with paleogeographical processes [32], with the maximum richness observed at the ecotonal region ranging between $34^{\circ}$ and $42^{\circ} \mathrm{S}$ in waters off Buenos Aires Province [20]. This region harbours more than 30 species of Rajiformes belonging to seven genera, four of which are endemic [32], constituting an area with a high degree of endemism and great diversity at global scale. Nonetheless, the information available about the parasites of elasmobranchs inhabiting the Argentine Sea is fragmentary. Particularly, the diversity of myxozoans in elasmobranch from this region has not been widely studied and only five species have been described, all belonging to the genus Chloromyxum Mingazzini, 1890 [64], namely: C. ovatum Jameson, 1929, C. liae Kuznetsova, 1977, C. transversocostatum Kuznetsova, 1977, C. multicostatum Kuznetsova, 1977 and C. parvicostatum Kuznetsova, 1977 [27, 44].

Chloromyxum is the fourth largest myxozoan genus (Cnidaria: Myxozoa) comprising about 140 nominal species $[25,72]$ commonly infecting the gall bladder of freshwater and marine fishes. In elasmobranchs, 25 Chloromyxum spp. with a worldwide distribution have been described so far see [35, 72]. Chloromyxum leydigi Mingazzini, 1890 [64], the type species, was originally described, without specifying the type host, from the gall bladder of numerous elasmobranch species ranked to different genera, namely Mustelus Fischer von Waldheim, Galeus Cuvier, Raja Linnaeus, Scyllium Cuvier, Squatina Duméril, Torpedo Houttuyn and Trygon Cuvier $[34,44,53,56,57,64,69,73]$. This suggests that $C$. leydigi is in fact an assemblage of several species [6, 35, 73], a phenomenon previously shown for other chloromyxids [12]. Nonetheless, C. leydigi gained specific identity through its morphological and ultrastructural redescription, and sequencing of the small subunit ribosomal DNA (SSU rDNA) from two different host species [28, 30,73]. In the last study, the type host (Torpedo marmorata Risso) and the type locality (Mediterranean Sea) of the parasite were assigned [73]. Previous studies have shown that Chloromyxum is a polyphyletic genus $[28,30]$, with its type species clustering with other myxozoans infecting the gall bladder of marine elasmobranchs to form the marine Chloromyxum clade [47], also named Chloromyxum sensu stricto clade [35], placed at the basis of the freshwater myxosporean lineages [28, 29, 31].

The present study provides the morphological and molecular description of two new species of Chloromyxum based on material collected from the gall bladder of two species of Rajiformes captured on the Atlantic coast of Argentina: the spotback skate Atlantoraja castelnaui (Miranda Ribeiro) (Arhynchobatidae) and the yellownose skate Zearaja chilensis (Guichenot) (Rajidae). An additional locality is also reported for C. riorajum Azevedo, Casal, Garcia, Matos, Teles-Grilo and Matos, 2009 collected from its type host, the Rio skate
Rioraja agassizii (Müller and Henle) (Arhynchobatidae) [8]. Analyses of their SSU rDNA sequences allowed us to evaluate their systematic relationships and phylogenetic position amongst other chloromyxids parasitising elasmobranchs within the marine Chloromyxum clade, emphasising the interpretation in relation to host identity and host geographic distribution.

\section{Materials and methods \\ Host and parasite collection and processing}

The gall bladders of a total of 217 skates belonging to 7 species were examined for myxosporean infections, including 22 specimens of the southern thorny skate Amblyraja doellojuradoi (Pozzi) (Rajidae), 14 specimens of A. castelnaui, 27 specimens of the white-dotted skate Bathyraja albomaculata (Norman) (Arhynchobatidae), 18 specimens of $R$. agassizii, 66 specimens of the bignose fanskate Sympterygia acuta Garman (Arhynchobatidae), 48 specimens of the smallnose skate S. bonapartii Müller and Henle (Arhynchobatidae), and 22 specimens of $Z$. chilensis, all obtained from commercial trawlers in waters off Buenos Aires Province $\left(34^{\circ}-42^{\circ} \mathrm{S}\right.$; $\left.53^{\circ}-62^{\circ} \mathrm{W}\right)$, Argentina during 2014.

Fish were kept fresh on ice until examination. Upon necropsy, the livers were removed entirely and the bile from the gall bladders was extracted by a sterile syringe. A drop of bile of each gall bladder was then placed on a microscope slide and examined using the Leica DM2500 stereoscopic microscope for the detection of myxosporeans. The rest of the bile of the parasitized fishes was then processed for observation by light microscopy (LM), scanning electron microscopy (SEM), and for molecular characterization.

Valid names of host species for previously recorded myxosporeans are in accordance with the Catalog of Fishes [26].

\section{Morphological analysis of myxospores by light microscopy}

Digital photographs of fresh myxospores observed under the differential interference contrast (DIC) were taken using the Leica DM2500 stereoscopic microscope equipped with the Leica DFC295 camera and then measured in ImageJ v.1.45 s [76]. Measurements of myxospores followed the guidelines proposed by Lom and Arthur [55] for species descriptions of Myxosporea. All measurements are given in micrometres as a mean \pm standard deviation $(S D)$, followed by range in parentheses and the number of myxospores measured for each myxospore dimension.

\section{Morphological analysis of myxospores by SEM}

The gall bladder contents of each host species showing high intensity of myxosporean infections were fixed in $2.5 \%$ (v/v) glutaraldehyde buffered in $0.2 \mathrm{M}$ sodium cacodylate ( $\mathrm{pH} 7.2$ ) for $24 \mathrm{~h}$ at $4{ }^{\circ} \mathrm{C}$, and then rinsed in the same buffer $(2 \times 30 \mathrm{~min})$ at the same temperature. The samples were then dehydrated in an ascending ethanol series, transferred into 50\% hexamethyldisilazane (HMDS) in 100\% ethanol followed by 
two changes of $100 \%$ HMDS each for 45 min (partially modified from Rocha and Azevedo [71]). A drop of sample was then put onto a coverslip, the excess of HMDS was allowed to air dry, and then the sample was coated with gold-palladium and observed and photographed with the JEOL JSM 6460-LV scanning electron microscope (JEOL, Tokyo, Japan).

\section{Morphometric comparison of myxospores}

Morphometric differences among Chloromyxum myxospores from different skate species were explored using the canonical analysis of principal coordinates (CAP) [3, 4]. Potential over-parameterisation was prevented by choosing the number of principal coordinates ordination (PCO) axes (m) that maximised a leave-one-out allocation success to groups [2]. CAP analyses were based on Euclidean distances on the variables myxospore thickness, length and width, and polar capsule length and width.

In addition to CAP analysis, differences in dimensions of Chloromyxum myxospores from different host species were tested using the one-way distance-based permutational multivariate analysis of variance (PERMANOVA) [1, 4]. PERMANOVA analysis was conducted over 9999 permutations under the default permutation method (permutation of residuals under a reduced model) and sum of squares type III (partial) [4]. When differences were detected by PERMANOVA, pairwise comparisons were used to determine which samples differed. Since PERMANOVA is sensitive to differences in multivariate dispersion among samples (sensu homogeneity of variances, which can inflate Type 1 error even when centroids have identical locations), differences in dispersion were tested using the routine PERMDISP [4]. Dispersions were measured as distances to the centroids and each term in the analysis was tested using 9999 permutations.

All multivariate statistical procedures on morphometric data were performed by PRIMER v.6. [18, 19] and PERMANOVA + for PRIMER [4].

\section{DNA extraction, PCR amplification, cloning and sequencing}

Selected positive samples were fixed and preserved in $96 \%$ ethanol at $4{ }^{\circ} \mathrm{C}$ for molecular characterization by sequencing of SSU rDNA. Each sample was pelleted twice at $3000 \mathrm{rpm}$ for $5 \mathrm{~min}$ and washed with DNAse-free water, and the ethanol was removed. Then samples were stored in $400 \mu \mathrm{L}$ TNES urea buffer $(10 \mathrm{mM}$ Tris- $\mathrm{HCl}$ with $\mathrm{pH} 8,125 \mathrm{mM} \mathrm{NaCl}, 10 \mathrm{mM}$ EDTA, 0.5\% SDS and $4 \mathrm{M}$ urea) [5] for subsequent DNA extraction. Total DNA was extracted by a simplified phenolchloroform extraction protocol [41], after an overnight digestion with proteinase $\mathrm{K}\left(50 \mu \mathrm{g} \mathrm{mL} \mathrm{m}^{-1}\right)$ at $55^{\circ} \mathrm{C}$. The extracted DNA was re-suspended in $50 \mu \mathrm{L}$ of sterile distilled water and left to dissolve at $4{ }^{\circ} \mathrm{C}$ until further use.

Almost complete SSU rDNA sequences of Chloromyxum species from $A$. castelnaui as well as from $Z$. chilensis, and partial SSU rDNA sequences of Chloromyxum species infecting $R$. agassizii were obtained by assembling overlapping parts amplified with both universal and myxozoan-specific primers. Thereby, the reaction with the universal eukaryotic
ERIB1 (5'-ACCTGGTTGATCCTGCCAG-3') and ERIB10 (5'-CTTCCGCAGGTTCACCTACGG-3') primers (both [11]) in the first PCR was followed by nested PCR with MyxGP2F (5'-TGGATAACCGTGGGAAA-3' [49]) and ACT1r (5'-AATTTCACCTCTCGCTGCCA-3' [36]) for all Chloromyxum species, and by ERIB1 + ACT1r and by MyxospecF $\left(5^{\prime}\right.$-TTCTGCCCTATCAACTWGTTG-3') + MyxospecR (5'GGTTTCNCDGRGGGMCCAAC-3') (both [28]) for Chloromyxum species from $A$. castelnaui and $Z$. chilensis. Additionally, for the Chloromyxum species from A. castelnaui and $Z$. chilensis, an overlapping part was also amplified with MyxospecF + ERIB10.

Polymerase chain reactions (PCRs) of the SSU rDNA were performed in a $25 \mu \mathrm{L}$ reaction using $1 \times$ Taq buffer, $250 \mu \mathrm{M}$ of each dNTPs, $10 \mathrm{pmol}$ of each primer, $1 \mathrm{U}$ of Taq-Purple polymerase (Top-Bio, Czech Republic), $1 \mu \mathrm{L}$ of DNA and sterile distilled water. PCR cycling parameters used for the amplification of SSU rDNA sequences for the primary/nested PCR were as follows: denaturation at $95{ }^{\circ} \mathrm{C}$ for $3 \mathrm{~min}$, then 30 cycles of amplification at $95{ }^{\circ} \mathrm{C}$ for $1 \mathrm{~min}, 48{ }^{\circ} \mathrm{C} / 50{ }^{\circ} \mathrm{C}$ for $1 \mathrm{~min}, 72^{\circ} \mathrm{C}$ for 1 or $2 \mathrm{~min}$ and followed by a $10 \mathrm{~min}$ extension at $72{ }^{\circ} \mathrm{C}$. All amplified products were purified using Gel/ PCR DNA Fragments Extraction Kit (Geneaid Biotech Ltd., USA).

Problematic amplicons with low DNA concentration for the amplified segment MyxospecF-ERIB10 of Chloromyxum species infecting $A$. castelnaui were cloned into the pDrive Vector with a Qiagen PCR Cloning Kit (Qiagen, Germany) and transformed into XL-1 E. coli strain competent cells. Positive colonies were PCR screened with M13 forward and reverse primers. Plasmid DNA was isolated using a High Pure Plasmid Isolation Kit (Roche Applied Science, Germany) and two colonies were sequenced. The PCR products and plasmids were commercially Illumina sequenced (https://www.seqme.eu).

\section{Phylogenetic analyses}

The overlapping partial sequences of SSU rDNA were assembled in SeqMan II v5.05 (DNASTAR Inc., Madison, Wisconsin, USA). New sequences were deposited in GenBank with accession numbers MG652633, MG652632 and MG652631. The SSU rDNA alignment was created in the MAFFT v7.017 [48] using E-INS-i strategy and default parameters (gap opening penalty: 1.53 and gap extension penalty $0.0)$. The alignment contained newly obtained sequences and all sequences of taxa of the elasmobranch-infecting Chloromyxum clade see $[35,72]$ retrieved from GenBank. Chloromyxum cristatum Léger, 1906 (GenBank accession no: AY604198) and Myxidium lieberkuehni Bütschli, 1882 (GenBank accession no: X76639) were set as the outgroup. Ambiguously aligned regions of the alignment were eliminated and the ends of the alignment were trimmed.

Phylogenetic analyses were performed using maximum likelihood (ML), maximum parsimony (MP) and Bayesian inference (BI). ML was done in the RAxML v7.0.3. [77] with GTR $+\Gamma$ model of evolution. MP was performed in the PAUP* v4.0b10 [78] using a heuristic search with random taxa addition and the tree bisection reconnection (TBR) swapping algorithm. All characters were treated as unordered, the $T_{\mathrm{s}}: T_{\mathrm{v}}$ 
ratio was set to $1: 2$ and gaps were treated as missing data. For ML and MP, clade supports were assessed with bootstrapping of 1000 replicates with random sequences additions. BI was conducted in MrBayes v3.0 [74] using the GTR $+\Gamma$ model of evolution. Posterior probabilities were estimated over 1000000 generations via two independent runs of four simultaneous Markov chain Monte Carlo chains with every 100th tree saved. Tracer v1.4.1 [70] was used to set the length of the burn-in period. Uncorrected $p$-distance were calculated with default parameters from the alignment using PAUP* v4.0b10.

\section{Results}

Plasmodia and mature myxospores of coelozoic myxozoans consistent with the morphological diagnosis of the genus Chloromyxum were observed floating freely in the bile of A. castelnaui, R. agassizii and Z. chilensis. No myxozoan infections were found in the gall bladder of the other four skates examined (A. doellojuradoi, B. albomaculata, S. acuta and $S$. bonapartii).

Morphological and molecular analysis of positive samples revealed the presence of two new species parasitizing A. castelnaui and $Z$. chilensis, respectively, and identified the third species, found in $R$. agassizii, as C. riorajum [8]. No macroscopic signs of infection were observed.

\section{Taxonomic position}

Phylum Cnidaria Hatschek, 1888

Subphylum Myxozoa Grassé, 1970

Class Myxosporea Bütschli, 1881

Order Bivalvulida Schulman, 1959

Suborder Variisporina Lom and Noble, 1984

Family Chloromyxidae Thélohan, 1892

Genus Chloromyxum Mingazzini, 1890

\section{Chloromyxum atlantoraji n. sp.}

urn:Isid:zoobank.org:act:65034C3F-2EC2-4A57-AA8B452DB8072337

Type host: the spotback skate, Atlantoraja castelnaui (Miranda Ribeiro) (Rajiformes: Arhynchobatidae).

Type locality: off the coast of Buenos Aires Province (34$\left.42^{\circ} \mathrm{S} ; 53^{\circ}-62^{\circ} \mathrm{W}\right)$, Argentina.

Localization of sporogonic stages: Plasmodia and myxospores floating in the bile.

Prevalence of infection: $35.7 \%$ (5 infected of 14 examined fishes).

Type material: syntype MLP-Oi 4150 (coverslip with goldpalladium coated sample for SEM) and voucher MLP-ZI-RG 417 (bile containing myxospores in absolute ethanol) deposited in the Other Invertebrates Collection and Genetic Resources Collection, respectively, Museo de La Plata, La Plata, Argentina.

DNA sequences. SSU rDNA sequence available in GenBank under the accession number MG652633. host.
Description (Figs. 1 and 2)

Sporogonic stages: plasmodia polysporic, highly polymorphic; spherical, oval or very irregular in shape. Dimensions varying greatly as a result of polymorphic nature of these structures.

Myxospores: mature myxospores ovoid with pointed anterior apex; $10.5 \pm 0.4(9.7-11.4, n=23)$ long in sutural view, $8.5 \pm 0.4$ wide $(7.7-9.4, n=23)$ and $8.8 \pm 0.6$ thick $(8.0$ $9.4, n=23)$. Myxospore wall composed of two equally sized valves adhering to each other along a slightly sinuous suture line. Each valve with 3-4 elevated surface ridges parallel to suture line and nearly parallel to each other, not reaching the apical pole. A bundle of long caudal filamentous projections, 3 or 4 times longer than the myxospore length, originating at the distal end of shell valves. Four anteriorly pointed, pyriform, equally-sized polar capsules, $3.5 \pm 0.3(3.0-4.5, n=23)$ in length and $2.4 \pm 0.2(1.9-3.0, n=23)$ in width. Number of polar filament coils not determined. Extrusion polar filament area located in a mild depression near anterior apex of each shell valve. Single sporoplasm irregular in shape, bearing two nuclei randomly positioned in its matrix.

\section{Taxonomic affinities}

Among the Chloromyxum sensu stricto representatives and taking into account myxospore dimensions (considering the minimum and maximum values of myxospore length, thickness and width provided in the literature), C. atlantoraji $\mathrm{n}$. sp. most closely resembles $C$. kuhlii Gleeson and Adlard, 2012, C. lesteri Gleeson and Adlard, 2012, C. leydigi Mingazzini, 1890, C. mingazzinii Gleeson and Adlard, 2012, C. pristiophori Woolcock, 1936, C. scyliorhinum Noble, 1948, C. schulmani Kovaljova, 1988, and C. striatellus Kovaljova, 1988. The new species can be distinguished from C. pristiophori by having smaller polar capsules (3.3-4.5 vs. 5.0-6.0). Furthermore, $C$. atlantoraji $\mathrm{n}$. sp. has a smaller number of elevated surface ridges (3, rarely 4 ridges) than $C$. kuhlii (4, rarely 5 ridges), $C$. lesteri (4, rarely 5 ridges), C. leydigi (4-5 ridges), C. scyliorhinum (5 ridges), C. schulmani (13 ridges), and C. striatellus (8 ridges). Moreover, the new species has very long caudal filamentous projections ( 3 or 4 times of the myxospore length), while all the above-mentioned species have much shorter ones. Indeed, in C. scyliorhinum, projections are as long as its myxospore length, whereas they are shorter than myxospore length in C. schulmani, C. striatellus, C. kuhlii, C. lesteri, and C. mingazzinii. Genetic differences among the elasmobranch-infecting Chloromyxum species that were genetically characterized (SSU rDNA) are shown in Table 1.

\section{Chloromyxum zearaji n. sp.}

urn:lsid:zoobank.org:act:935ED1FB-732D-43A2-82F219781FF682EF

Type host: yellownose skate Zearaja chilensis (Guichenot) (Rajiformes: Rajidae)

Type locality: off the coast of Buenos Aires Province (34$\left.42^{\circ} \mathrm{S} ; 53^{\circ}-62^{\circ} \mathrm{W}\right)$, Argentina.

Localization of sporogonic stages: plasmodia and myxospores freely floating in the bile. 

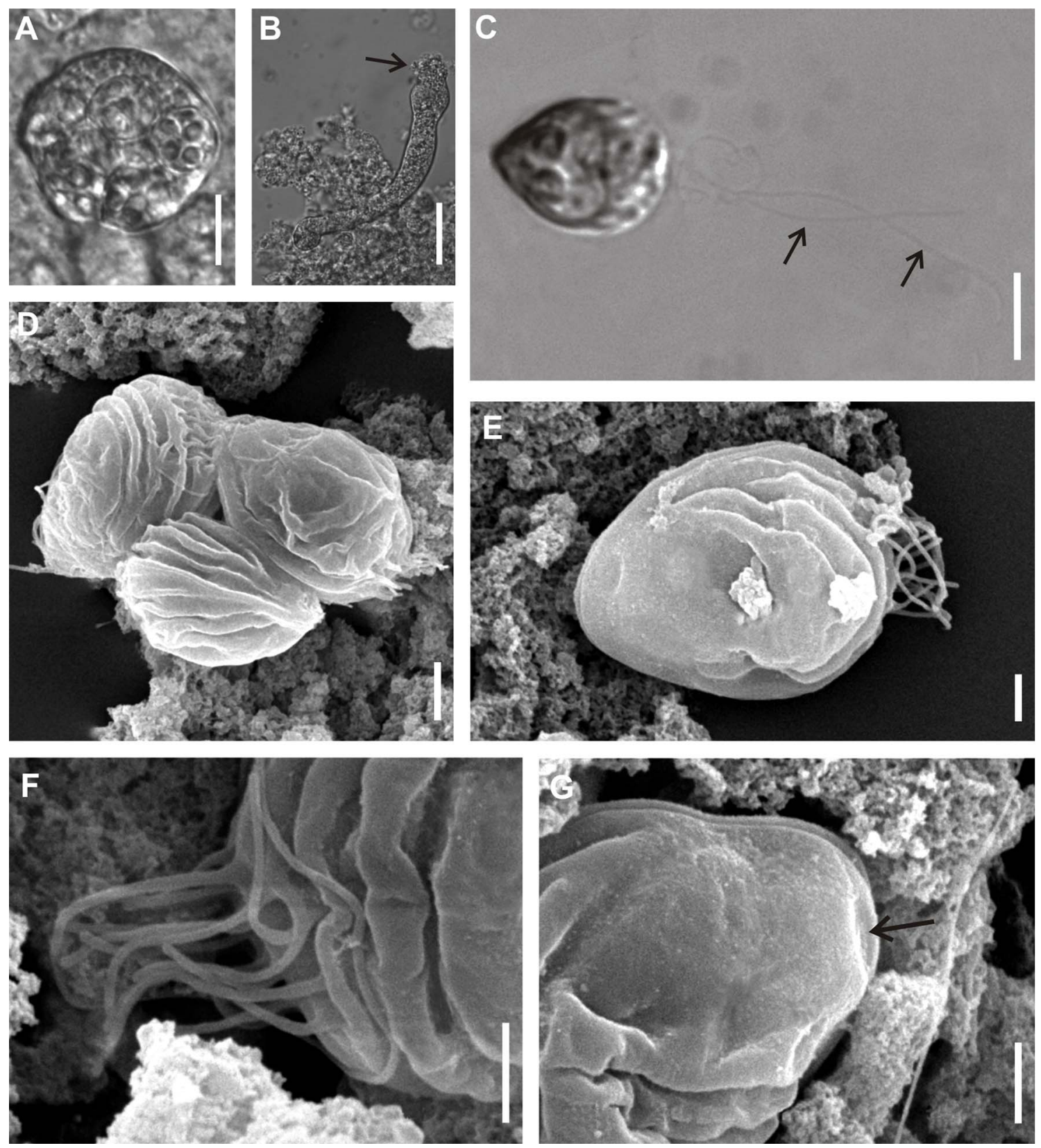

Figure 1. Chloromyxum atlantoraji n. sp. from the gall bladder of the spotback skate, Atlantoraja castelnaui (Miranda Ribeiro) (Arhynchobatidae, Rajiformes). (A) Spherical polysporic plasmodium (DIC micrographs). (B) Plasmodium displaying highly irregular shape morphology with the presence of peripheral projections (arrow) (DIC micrographs). (C) Mature myxospore showing caudal filamentous projections (arrows), valvular view (DIC micrographs). (D) Mature myxospores, sutural and medial views (SEM). (E) Mature myxospore, valvular view (SEM). (F) Detail of the caudal bundle of filamentous projections (SEM). (G) Detail of the anterior apex showing the mild depression area for polar filaments extrusion (arrow) (SEM). Scale bars: $A=10 \mu \mathrm{m} ; \mathrm{B}=20 \mu \mathrm{m} ; \mathrm{C}=5 \mu \mathrm{m} ; \mathrm{D}, \mathrm{F}, \mathrm{G}=1 \mu \mathrm{m} ; \mathrm{E}=2 \mu \mathrm{m}$

Prevalence of infection: $45.5 \%$ (10 infected in 22 examined fishes).

Type material: Syntype MLP-Oi 4151 (coverslip with goldpalladium coated sample for SEM); voucher MLP-ZI-RG 418 (bile containing myxospores in absolute ethanol) deposited in the Other Invertebrates Collection and Genetic Resources Collection, respectively, Museo de La Plata, La Plata, Argentina.

DNA sequences. SSU rDNA sequence available in GenBank under the accession number MG652632.

Etymology: specific epithet refers to the generic name of its host.

\section{Description (Figs. 3 and 4)}

Sporogonic stages: plasmodia polysporic, highly polymorphic; spherical, oval or very irregular. Dimensions varying greatly as a result of polymorphic nature of these structures.

Myxospores: mature myxospores ovoid with pointed anterior apex; $11.6 \pm 0.4(10.8-12.4, n=23)$ long in sutural view, $9.6 \pm 0.5(9.0-10.4, n=23)$ wide and $9.8 \pm 0.4(9.0-10.6$, $n=23$ ) thick. Myxospore wall composed of two equally sized valves adhering to each other along a slightly sinuous suture line. Each valve with 5-6 elevated surface ridges parallel to the suture line and nearly parallel to each other and not 

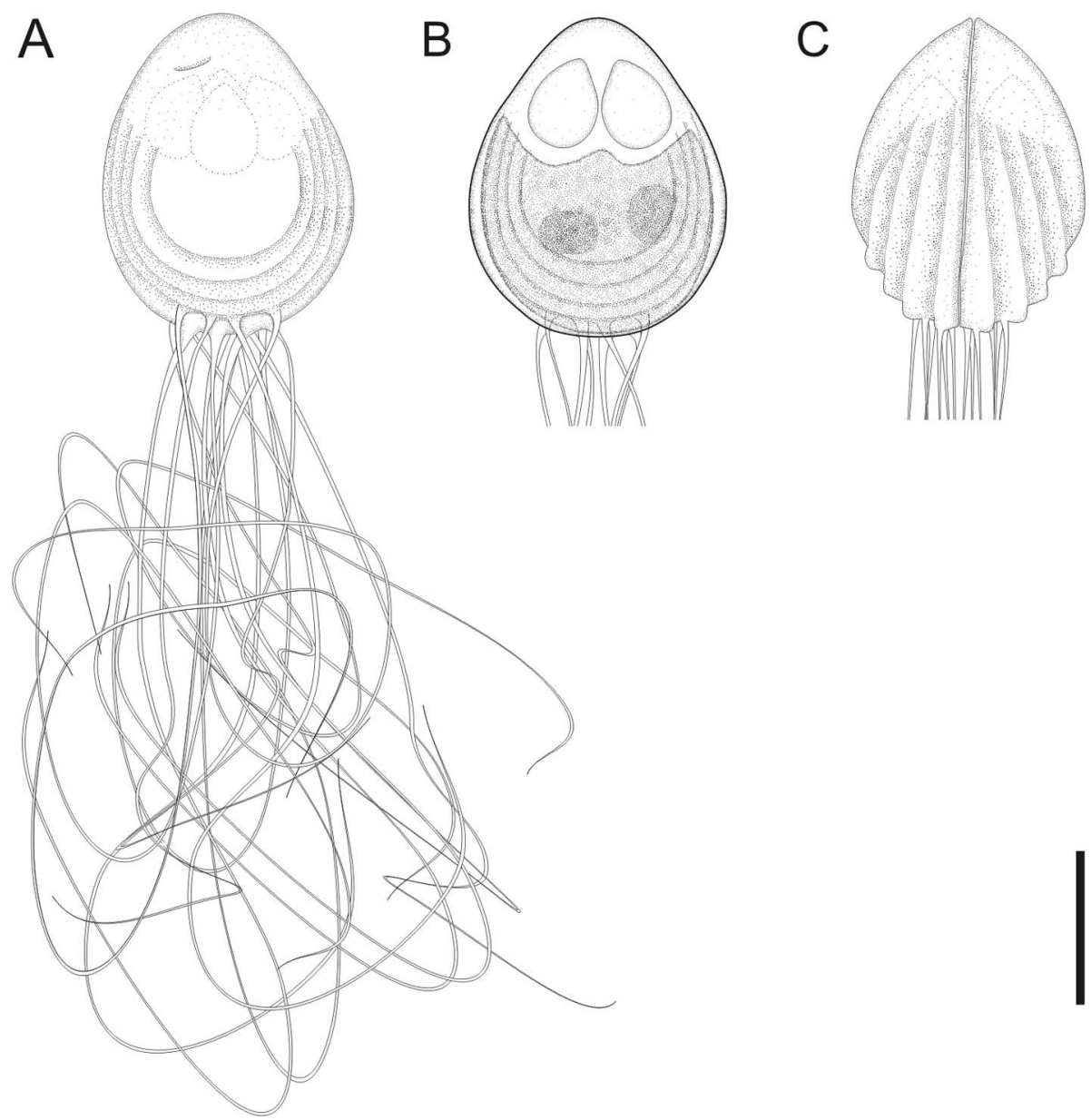

Figure 2. Schematic drawing a myxospore of Chloromyxum atlantoraji $\mathrm{n}$. sp. from the gall bladder of the spotback skate, Atlantoraja castelnaui (Miranda Ribeiro) (Arhynchobatidae, Rajiformes). (A) Valvular view of a mature myxospore. (B) Valvular view of a mature spore showing a single sporoplasm bearing two nuclei. (C) Sutural view of a mature myxospore, caudal filamentous projections not fully drawn. Scale bars: A, B, C $=5 \mu \mathrm{m}$.

Table 1. Uncorrected- $p$ distance with percentages of sequence similarities (above diagonal) and the number of nucleotide substitutions (below diagonal) among the 14 sequences of Chloromyxum spp. included in this study, based on a 1650 bp alignment of the SSU DNA.

\begin{tabular}{|c|c|c|c|c|c|c|c|c|c|c|c|c|c|c|}
\hline & 1 & 2 & 3 & 4 & 5 & 6 & 7 & 8 & 9 & 10 & 11 & 12 & 13 & 14 \\
\hline $\begin{array}{l}1 \text { Chloromyxum zearaji } \mathrm{n} \text {. } \mathrm{sp} \text {. } \\
\text { MG652632 }\end{array}$ & & 99.25 & 96.02 & 93.31 & 93.75 & 93.79 & 95.03 & 94.78 & 96.22 & 94.53 & 94.63 & 93.50 & 93.91 & 90.58 \\
\hline $\begin{array}{l}2 \text { C. atlantoraji n. sp. } \\
\text { MG652633 }\end{array}$ & 12 & & 96.03 & 93.55 & 93.45 & 3.55 & 94.60 & 94.42 & 95.87 & 4.40 & 4.42 & 3.06 & 93.54 & 90.52 \\
\hline 3 C. riorajum FJ62448 & 64 & 64 & & 99.88 & 93.13 & 92.80 & 2 & 9 & 95.42 & 93.95 & 94.19 & & 93.10 & 89.93 \\
\hline 4 C. $r$ & 55 & 53 & 1 & & 88.73 & 88.44 & & & 92.02 & & & & 88.92 & 82.40 \\
\hline $5 C$ & 101 & 106 & 111 & 93 & & 96.18 & 97 & 97 & 98 & & 96.99 & & 97.20 & 90.91 \\
\hline$C$ & 100 & 104 & 116 & 95 & 62 & & 96.71 & 96.40 & 97.24 & 96.29 & 95.65 & 90 & 95.83 & 90.80 \\
\hline$C$ & 68 & 74 & 75 & 58 & 40 & 45 & & 96.63 & 97.22 & 95.91 & 95.76 & 94.83 & 97.00 & 90.75 \\
\hline$C$ & 71 & 76 & 79 & 61 & 39 & 49 & 46 & & 97.72 & 97.86 & 96.33 & 95.26 & 97.06 & 90.42 \\
\hline $\begin{array}{l}9 \text { Chloromyxum sp. ex } S \text {. } \\
\text { acanthias JN130384 }\end{array}$ & 52 & 57 & 63 & 47 & 17 & 38 & 38 & 31 & & 97.08 & 96.88 & 96.01 & 98.55 & 91.23 \\
\hline 10 C. lesteri JN130377 & 75 & 77 & 83 & 61 & 46 & 51 & 56 & 29 & 40 & & 96.28 & 94.90 & 96.72 & 90.86 \\
\hline 11 C. kuhlii JN130375 & 74 & 77 & 80 & 60 & 42 & 60 & 58 & 50 & 43 & 51 & & 94.01 & 96.51 & 90.80 \\
\hline $12 C . h$ & 88 & 94 & 96 & 70 & 55 & 69 & 70 & 64 & 54 & 69 & 81 & & 95.64 & 90.1 \\
\hline $13 C . l$ & 98 & 104 & 111 & 91 & 45 & 67 & 41 & 40 & 20 & 45 & 48 & 59 & & 90.5 \\
\hline 14 C. myliobati JN130380 & 130 & 131 & 139 & 104 & 126 & 127 & 127 & 131 & 121 & 126 & 127 & 134 & 131 & \\
\hline
\end{tabular}

* Partial sequence ( $821 \mathrm{nt}$ from $5^{\prime}$ end). 

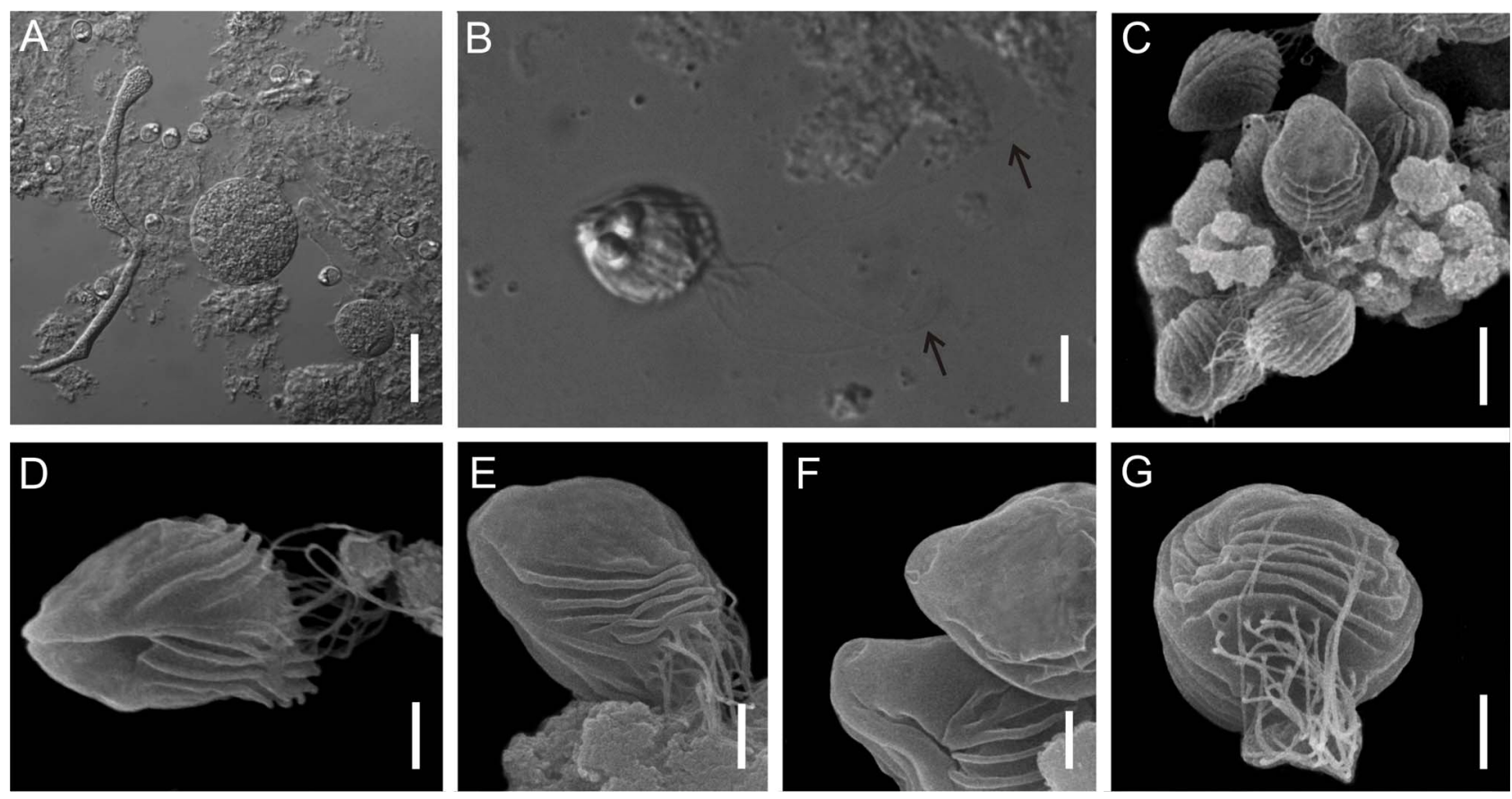

Figure 3. Chloromyxum zearaji n. sp. from the gall bladder of the yellownose skate, Zearaja chilensis (Guichenot) (Rajidae, Rajiformes). (A) Polymorphic plasmodia and myxospores free in the bile; (B) Mature myxospore showing caudal filamentous projections (arrow), sutural view (DIC micrographs); (C-E) Mature myxospores; (F) Detail of the anterior apex of two myxospores showing the mild depression area for polar filaments extrusion; (G) Mature myxospore, caudal view. Scale bars: $A=40 \mu \mathrm{m} ; \mathrm{B}, \mathrm{C}=5 \mu \mathrm{m} ; \mathrm{D}, \mathrm{E}, \mathrm{G}=2 \mu \mathrm{m} ; \mathrm{Fig}$. F $=1 \mu \mathrm{m}$.

reaching the apical pole. A bundle of very long caudal filamentous projections, 3 times longer than the myxospore length, originating from the basal portion of shell valves. Four anteriorly pointed, pyriform, equally-sized polar capsules, $3.9 \pm 0.3$ $(3.1-4.6, n=23)$ in length and $2.7 \pm 0.3(2.1-3.2, n=23)$ in width. Number of polar filaments coils not determined. Extrusion polar filament area located in a mild depression near anterior apex of each shell valve. Single sporoplasm irregular in shape, bearing two nuclei randomly positioned in its matrix.

\section{Taxonomic affinities}

Among the Chloromyxum sensu stricto representatives and taking into account myxospore dimensions (considering the minimum and maximum values of myxospore length, thickness and width provided in the literature), C. zearaji $\mathrm{n}$. sp. most closely resembles $C$. hemiscyllii Gleeson and Adlard, 2012, C. kuhlii Gleeson and Adlard, 2012, C. leydigi Mingazzini, 1890, C. myliobati Gleeson and Adlard, 2012, C. ovatum Jameson, 1929, C. scyliorhinum Noble, 1948, Chloromyxum sp. ex $S$. acanthias, and C. squali Gleeson and Adlard, 2012. However, C. zearaji n. sp. has a larger number of elevated surface ridges (5, rarely 6 ridges) compared to $C$. hemiscyllii (no visible surface ridges), C. kuhlii (4, rarely 5 ridges), C. myliobati (3-4 ridges), and $C$. ovatum (3-4 ridges). In addition, the new species has very long caudal filamentous projections ( 3 times the myxospore length) while in C. hemiscyllii, C. kuhlii, C. myliobati, C. ovatum, C. scyliorhinum, Chloromyxum sp. ex S. acanthias and $C$. squali projections are either equal to or shorter than myxospore length. Moreover, the new species can be distinguished from C. scyliorhinum by having slightly larger (3.14.6 vs. 3) and wider (2.1-3.2 vs. 1.9) polar capsules.
Chloromyxum zearaji can be distinguished from its sympatric congener $C$. atlantoraji n. sp. by myxospore dimensions; being myxospores of $C$. zearaji larger (10.8-12.4 vs. 9.7-11.4), thicker (9.0-10.4 vs. 7.7-9.4) and wider (9.0-10.4 vs. 8.0-9.4), and by having larger number of elevated surface ridges (5-6 ridges vs. 3-4 ridges). Genetic differences among the elasmobranch-infecting Chloromyxum species that were genetically characterized (SSU rDNA) are shown in Table 1.

\section{Chloromyxum riorajum Azevedo, Casal, Garcia, Matos, Teles-Grilo and Matos, 2009}

Host: Rio skate Rioraja agassizii (Müller and Henle) (Rajiformes: Arhynchobatidae)

Locality: off the coast of Buenos Aires Province (34$\left.42^{\circ} \mathrm{S} ; 53^{\circ}-62^{\circ} \mathrm{W}\right)$, Argentina.

Localization of sporogonic stages: plasmodia and myxospores floating in the bile.

Prevalence of infection: $83.3 \%$ (15 infected in 18 examined fishes).

Material deposited: vouchers MLP_Oi 4952 (coverslip with gold-palladium coated sample for SEM) and MLP-ZIRG 419 (bile containing myxospores in absolute ethanol) deposited in the Other Invertebrates Collection and Genetic Resources Collection, respectively, Museo de La Plata, La Plata, Argentina.

DNA sequences. SSU rDNA sequence available in GenBank under the accession number MG652631.

Remarks (Fig. 5)

Myxospore dimensions obtained in the present work agree with those reported in the original descriptions of $C$. riorajum 

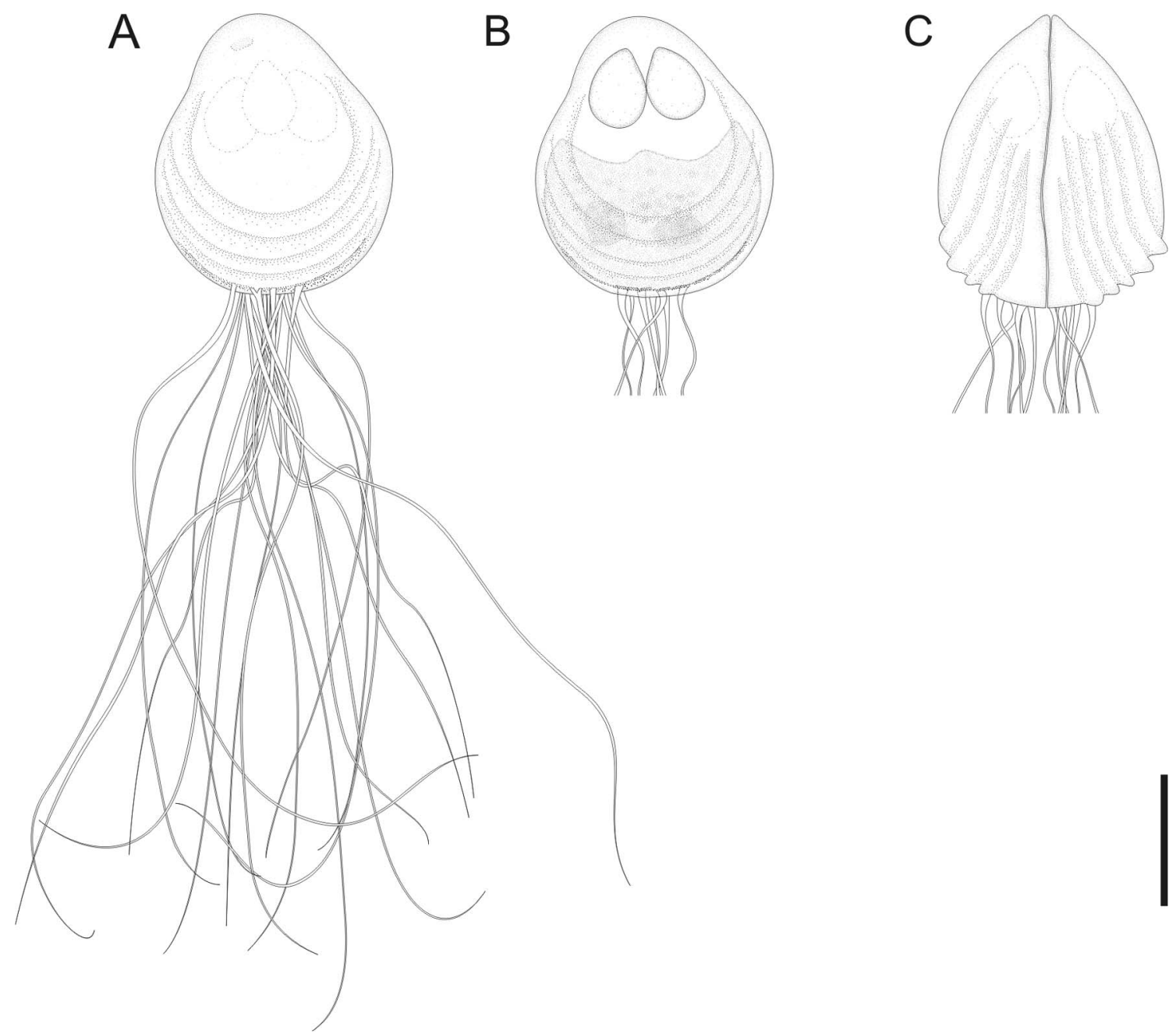

Figure 4. Schematic drawing a myxospore of Chloromyxum zearaji $\mathrm{n}$. sp. from the gall bladder of the yellownose skate, Zearaja chilensis (Guichenot) (Rajidae, Rajiformes). (A) Valvular view of a mature myxospore. (B) Valvular view of a mature spore showing a single sporoplasm bearing two nuclei. (C) Sutural view of a mature myxospore, caudal filamentous projections not fully drawn. Scale bars: A, $\mathrm{B}=5 \mu \mathrm{m}$.

[8]. Moreover, the SSU rDNA partial sequence of $C$. riorajum obtained from $R$. agassizii captured off the coast of Buenos Aires Province, Argentina was almost identical ( $0.1 \%$ sequence divergence) with the published partial sequence of $C$. riorajum (GenBank accession no: FJ624481) obtained from the same host from the South Atlantic coast of Brazil.

\section{Morphometric comparison of myxospores}

The CAP analysis showed significant morphometric differences between Chloromyxum myxospores from the three skate species. The selected orthonormal PCO axes $(m=5)$, described $100 \%$ of the variation in the data cloud, with a high percentage of correct allocations (92.76\%) (Fig. 6).

Results of PERMANOVA analyses showed significant morphometric variability among myxospores from the three host species $\left(\right.$ Pseudo- $F_{2,66}=59.708, P($ perm $\left.)=0.0001\right)$. Pairwise tests between samples showed that there were significant differences for all comparisons (for all pairwise comparisons $P($ perm $)=0.0001)$. None of these differences can be attributed to differences in multivariate dispersions of myxospore mea- surements in terms of their deviations from centroids, since PERMDISP results were not significant $\left(F_{2,66}=1.22\right.$, $P($ perm $)>0.05)$.

\section{Molecular characterization and phylogeny}

The assemblages of amplified sequences resulted in consensus of almost complete SSU rDNA sequences of $C$. atlantoraji n. sp. (1804 bp) and C. zearaji n. sp. (1828 bp) and of partial sequence of $C$. riorajum $(821 \mathrm{bp})$. These sequences were aligned with 11 SSU rDNA of the species that form the Chloromyxum sensu stricto clade and two sequences selected as outgroup (Table 2). The resulting alignment consisted of 1650 positions.

Maximum likelihood analyses of the SSU rDNA sequences revealed that sequences of Chloromyxum spp. from Rajiformes of the Atlantic coast of Argentina and the sequence of $C$. riorajum (GenBank accession no: FJ624481) from Brazilian waters group together, and form a sister clade to the rest of the Chloromyxum sensu stricto spp. (Fig. 7). MP analysis showed very similar topology differing from ML in basal posi- 

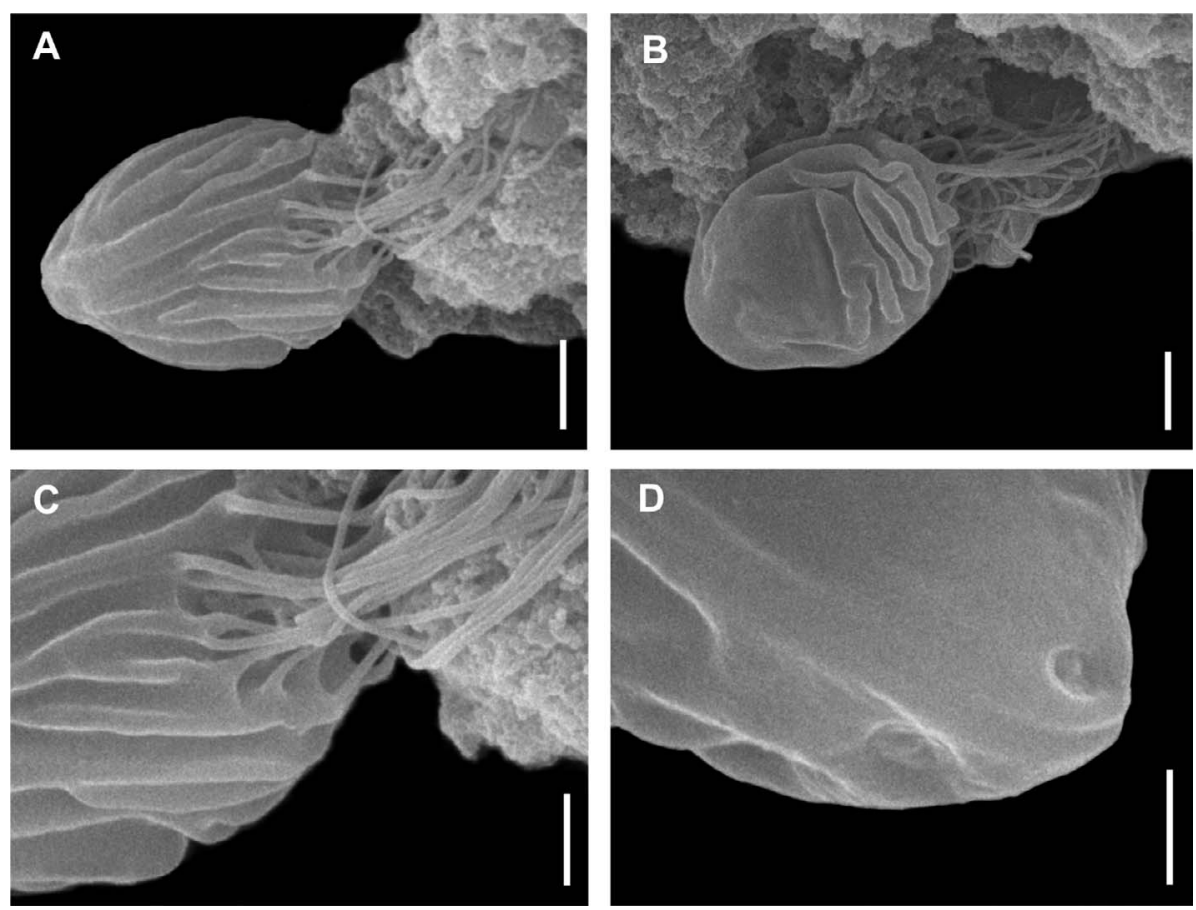

Figure 5. Chloromyxum riorajum Azevedo, Casal, García, Matos, Teles-Grilo and Matos, 2009 from the gall bladder of the Rio skate, Rioraja agassizii (Müller and Henle) (Arhynchobatidae, Rajiformes); scanning electron micrographs. (A) Mature myxospore, sutural view; (B) Mature myxospore, valvular view; (C) Detail of the caudal bundle of filaments; (D) Detail of the anterior apex showing the mild depression area for polar filaments extrusion. Scale bars: $A, B=2 \mu \mathrm{m} ; \mathrm{C}, \mathrm{D}=1 \mu \mathrm{m}$.

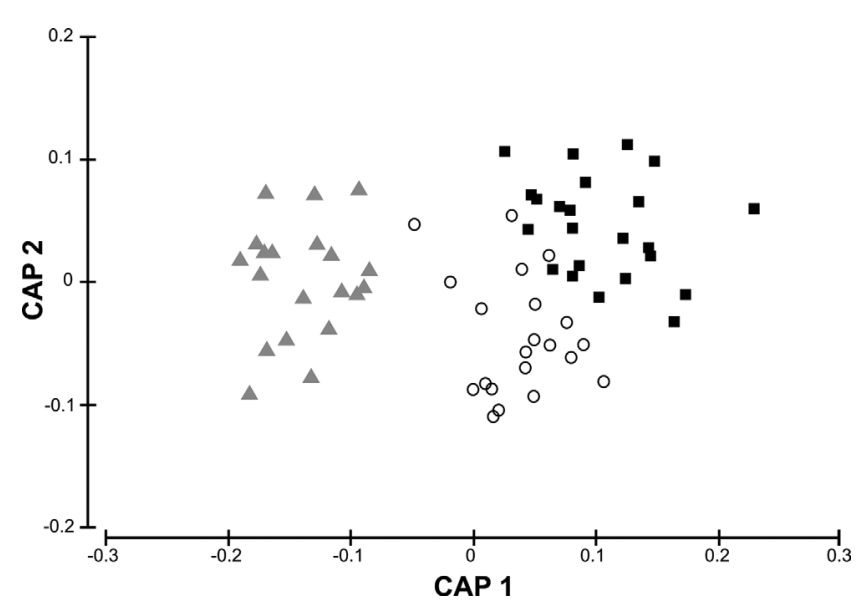

Figure 6. Canonical analysis of principal coordinates (CAP) based on Euclidean distance showing the axes that best discriminate morphometric differences among Chloromyxum myxospores from different skate species ( $\Delta$ the yellownose skate, Zearaja chilensis (Guichenot) (Rajidae, Rajiformes), ${ }^{\circ}$ the spotback skate, Atlantoraja castelnaui (Miranda Ribeiro) (Arhynchobatidae, Rajiformes) and the Rio skate, Rioraja agassizii (Müller and Henle) (Arhynchobatidae, Rajiformes)) obtained from commercial trawlers in waters off Buenos Aires Province $\left(38^{\circ}-42^{\circ} \mathrm{S}\right)$, Argentina during 2014.

tion of C. myliobati to all chloromyxid spp. (data not shown). BI analysis did not resolve the position of $C$. myliobati and resulted in the polytomy of this species and the clade with chloromyxids from the Atlantic coast of Argentina and the sequence of C. riorajum (FJ624481) and the clade containing the rest of Chloromyxum spp. The trees are typical for their overall low nodal support except for the highly supported clade (maximum nodal support in all analysis) of the Chloromyxum spp. from the Atlantic coast of Argentina and the sequence of C. riorajum (FJ624481).

The analyses of interspecies SSU rDNA sequences distances based on a $1650 \mathrm{bp}$ alignment revealed a minimum sequence dissimilarity between $C$. atlantoraji n. sp. and $C$. zearaji n. sp. (12 nt changes, $0.75 \%$ dissimilarity); whereas the greatest genetic distance was obtained between $C$. riorajum (FJ624481) and C. myliobati (JN130380) (139 nt changes, $10.07 \%$ dissimilarity) (Table 1 ). Within the only well-defined and statistically supported monophyletic subclade embracing Chloromyxum species from Rajiformes from the South West Atlantic Ocean (Fig. 7), the similarity among species with almost complete sequences ranged from $96.02 \%$ to $99.25 \%$, corresponding to a minimum of 12 and a maximum of 64 nucleotide substitutions (Table 1). Comparison of the partial sequence of $C$. riorajum from Rioraja agassizii from the coast of Buenos Aires province with C. riorajum from the same host from the South Atlantic coast of Brazil revealed one nucleotide difference (99.88\% similarity).

\section{Discussion}

The examination of 217 gall bladders from seven skate species, representatives of two families of Rajiformes that inhabit waters off the Buenos Aires Province in the Argentine sea, resulted in the finding of three species of Chloromyxum in 
Table 2. Chloromyxum species included in this study, ordered alphabetically.

\begin{tabular}{|c|c|c|c|c|c|c|}
\hline Species & $\begin{array}{c}\text { GenBank } \\
\text { accession no. }\end{array}$ & $\begin{array}{l}\text { Length of } \\
\text { sequence }\end{array}$ & Host & Host Family: Order & Locality & Reference \\
\hline $\begin{array}{l}\text { Chloromyxum } \\
\text { atlantoraji } \mathrm{n} . \mathrm{sp} .\end{array}$ & MG652633 & 1804 & $\begin{array}{l}\text { Atlantoraja castelnaui } \\
\text { (Miranda Ribeiro) }\end{array}$ & $\begin{array}{l}\text { Arhynchobatidae: } \\
\text { Rajiformes }\end{array}$ & $\begin{array}{l}\text { South Atlantic, } \\
\text { coast of } \\
\text { Argentina }\end{array}$ & Present study \\
\hline C. clavatum & JQ793641 & 1844 & Raja clavata Linnaeus & Rajidae: Rajiformes & $\begin{array}{l}\text { Atlantic coast of } \\
\text { Portugal }\end{array}$ & {$[72]$} \\
\hline C. hemiscyllii & JN130374 & 1355 & $\begin{array}{l}\text { Hemiscyllium } \\
\text { ocellatum } \\
\text { (Bonnaterre) }\end{array}$ & $\begin{array}{l}\text { Hemiscylliidae: } \\
\text { Orectolobiformes }\end{array}$ & Australian waters & {$[35]$} \\
\hline C. kuhlii & JN130375 & 1386 & $\begin{array}{l}\text { Neotrygon kuhlii } \\
\text { (Müller and Henle) }\end{array}$ & $\begin{array}{l}\text { Dasyatidae: } \\
\text { Myliobatiformes }\end{array}$ & Australian waters & {$[35]$} \\
\hline C. lesteri & JN130377 & 1379 & $\begin{array}{l}\text { Cephaloscyllium } \\
\text { laticeps (Duméril) }\end{array}$ & $\begin{array}{l}\text { Scyliorhinidae: } \\
\text { Carcharhiniformes }\end{array}$ & Australian waters & {$[35]$} \\
\hline C. leydigi & DQ377710 & 1866 & $\begin{array}{l}\text { Centroscymnus } \\
\text { coelolepis Barbosa } \\
\text { du Bocage and de } \\
\text { Brito Capello }\end{array}$ & $\begin{array}{l}\text { Somniosidae: } \\
\text { Squaliformes }\end{array}$ & $\begin{array}{l}\text { North Atlantic, } \\
\text { coast of USA }\end{array}$ & {$[28]$} \\
\hline C. leydigi & AY604199 & 1868 & $\begin{array}{l}\text { Torpedo marmorata } \\
\text { Risso }\end{array}$ & $\begin{array}{l}\text { Torpedinidae: } \\
\text { Torpediniformes }\end{array}$ & $\begin{array}{l}\text { Mediterranean Sea, } \\
\text { coast of Croatia }\end{array}$ & {$[30]$} \\
\hline C. mingazzinii & JN130379 & 1366 & $\begin{array}{l}\text { Pristiophorus } \\
\quad \text { nudipinnis Günther }\end{array}$ & $\begin{array}{l}\text { Pristiophoridae: } \\
\text { Pristiophoriformes }\end{array}$ & Australian waters & {$[35]$} \\
\hline C. myliobati & JN130380 & 1400 & $\begin{array}{l}\text { Myliobatis australis } \\
\text { Macleay }\end{array}$ & $\begin{array}{l}\text { Myliobatidae: } \\
\text { Myliobatiformes }\end{array}$ & Australian waters & {$[35]$} \\
\hline C. riorajum & MG652631 & 821 & $\begin{array}{l}\text { Rioraja agassizii } \\
\quad \text { (Müller and Henle) }\end{array}$ & $\begin{array}{l}\text { Arhynchobatidae: } \\
\text { Rajiformes }\end{array}$ & $\begin{array}{l}\text { South Atlantic, } \\
\text { coast of } \\
\text { Argentina }\end{array}$ & Present study \\
\hline C. riorajum & FJ624481 & 1807 & $\begin{array}{l}\text { Rioraja agassizii } \\
\quad \text { (Müller and Henle) }\end{array}$ & $\begin{array}{l}\text { Arhynchobatidae: } \\
\text { Rajiformes }\end{array}$ & $\begin{array}{l}\text { South Atlantic, } \\
\text { coast of Brazil }\end{array}$ & [8] \\
\hline C. squali & JN130381 & 1381 & $\begin{array}{l}\text { Squalus acanthias } \\
\text { Linnaeus }\end{array}$ & $\begin{array}{l}\text { Squalidae: } \\
\text { Squaliformes }\end{array}$ & Australian waters & {$[35]$} \\
\hline C. zearaji n. sp. & MG652632 & 1828 & $\begin{array}{l}\text { Zearaja chilensis } \\
\text { (Guichenot) }\end{array}$ & Rajidae: Rajiformes & $\begin{array}{l}\text { South Atlantic, } \\
\text { coast of } \\
\text { Argentina }\end{array}$ & Present study \\
\hline C. sp. ex S. acanthias & JN130384 & 1399 & $\begin{array}{l}\text { Squalus acanthias } \\
\text { Linnaeus }\end{array}$ & $\begin{array}{l}\text { Squalidae: } \\
\quad \text { Squaliformes }\end{array}$ & Australian waters & {$[35]$} \\
\hline
\end{tabular}

three host species. Their morphological and genetic (SSU rDNA) characterization showed that they represent two new and one previously described species.

Traditionally, the taxonomy of the Myxozoa has been largely based on the morphology and morphometrics of the myxospore stages, resulting in many taxonomic ambiguities [57] due to the simplicity of the microscopic myxospores, to the small number of measurable characters and to their considerable morphological plasticity that result in convergent morphotypes [29]. These features pose difficulties for species identification and discrimination when myxospore attributes are analyzed individually. Nevertheless, the use of multivariate procedures on a set of myxospore measurements (e.g. CAP and PERMANOVA) clearly differentiated the three Chloromyxum species considered here, even though some characters displayed overlapping ranges, demonstrating the utility of these methods for specific discrimination purposes.

In any case, the combination of morphological, genetic, and biological information (e.g. geographic locality, host species, tissue tropism, etc.) enables comprehensive informative taxonomic discrimination at the species level. Therefore, the erection of new species should always be accompanied by the application of comprehensive morphological and biological data, as well as molecular analyses to warrant an accurate description [42, 50, 57].

The first taxonomic studies of elasmobranch-infecting Chloromyxum, that pre-date the molecular era, were solely based on morphological comparison of myxospores using LM observations [7, 34, 44, 52, 54, 69]. The lack of implementation of ultrastructural (TEM and SEM) and molecular approaches led to poor descriptions that provided few reliable features for taxonomic comparison and led to erroneous identifications. This is also the case of the five Chloromyxum species thus far registered in the Atlantic coast of Argentina by Kuznetsova [54], (i) C. ovatum from Mustelus californicum [valid as Mustelus californicus Gill] (Triakidae), Squalus sucklii [valid as Squalus suckleyi (Girard)] (Squalidae), Galeorchinus zyopterus [valid as Galeorhinus galeus (Linnaeus)] (Triakidae), Tetraonarce californica [valid as Tetronarce californica (Ayres)] (Torpedinidae) and Prionace glauca (Linnaeus) (Carcharhinidae); (ii) C. liae from P. glauca; (iii) C. transversocostatum from Squalus fernandinus [valid as Squalus acanthias Linnaeus] (Squalidae); (iv) C. multicostatum from Squatina squatina (Linnaeus) (Squatinidae), and (v) C. parvicostatum 


\begin{tabular}{|c|c|c|}
\hline Torpediniformes & Chloromyxum leydigi AY604199 & Mediterranean Sea \\
\hline Orectolobiformes & L_ Chloromyxum hemiscyllii JN130374 & Australian Waters \\
\hline Squaliformes & - Chloromyxum leydigi DQ377710 & North West Atlantic \\
\hline Squaliformes & L Chloromyxum sp. JN130384 & Australian Waters \\
\hline $\begin{array}{l}\text { Carcharhiniformes } \\
\text { Pristiophoriformes }\end{array}$ & {$\left[\begin{array}{l}\text { Chloromyxum lesteri JN130377 } \\
-170 / 0.91 \\
\text { Chloromyxum mingazzinii JN130379 } \\
-185 / 0.82\end{array}\right.$} & $\begin{array}{l}\text { Australian Waters } \\
\text { Australian Waters }\end{array}$ \\
\hline $\begin{array}{l}\text { Squaliformes } \\
\text { Rajiformes }\end{array}$ & $\begin{array}{l}\text { Chloromyxum squali JN130381 } \\
\text { 58/-10.85 } \\
\text { Chloromyxum clavatum JQ793641 }\end{array}$ & $\begin{array}{l}\text { Australian Waters } \\
\text { North West Atlantic }\end{array}$ \\
\hline Myliobatiformes & L Chloromyxum kuhili JN130375 & Australian Waters \\
\hline Myliobatiformes & Chloromyxum myliobati JN130380 & Australian Waters \\
\hline Rajiformes & 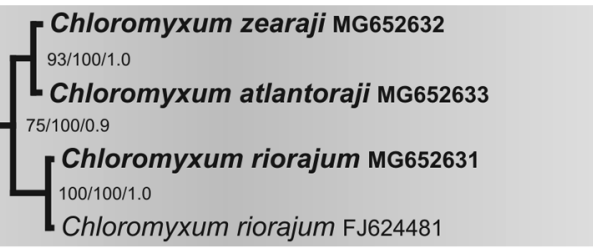 & South West Atlantic \\
\hline
\end{tabular}

Figure 7. The maximum likelihood tree showing the phylogenetic position of Chloromyxum species with new sequence data within Chloromyxum s.s. clade. Chloromyxum cristatum Léger, 1906 (GenBank accession no: AY604198) and Myxidium lieberkuehni Bütschli, 1882 (GenBank accession no: X76639) were set as the outgroup, their common branch shortened to 50\% of the original length. Nodal supports are indicated for ML (1000 replicates, only bootstrap values greater than 50\% are shown), MP (1000 replicates only bootstrap values greater than $50 \%$ are shown) and BI (only posterior probabilities greater than 0.8 are shown). Bold branches lead to nodes highly supported $(>70 \%$ for ML and MP, and $>0.8$ for BI) and dashes indicate bootstrap values $<50$ or node not present in the MP or BI tree. Newly sequenced taxa in bold. Species names are supplemented with corresponding GenBank accession numbers. Host taxonomic order and its geographic distribution are stated at the left and right sides of the ML tree respectively. The number of changes per site is given by the scale bar.

from Raja brachyurops [valid as Bathyraja brachyurops (Fowler)] (Arhynchobatidae) and Raja magellanica [valid as Bathyraja magellanica (Philippi)] (Arhynchobatidae).

There are several drawbacks within Kuznetsova's [54] work. Firstly, the species descriptions certainly do not meet current requirements in order to accomplish an accurate taxonomic description and could hinder correct designation of existing as well as new species. Secondly, some of the host species of Chloromyxum spp. reported from the Argentine Sea are not distributed in this region. Indeed, M. californicus and S. suckleyi are restricted to the North Pacific Ocean; T. californica is limited to the Eastern Pacific Ocean and Japan coast, and $S$. squatina only inhabits waters of the North Atlantic Ocean [33]. Myxozoans are mostly host-specific parasites in their fish hosts; with individual parasites species developing in only one host species or in a limited number of closely related ones $[65,66]$, which is why host identity has become an important character in myxozoan taxonomy and their correct identification is mandatory. Lastly, it should be mentioned that $C$. ovatum is now considered an assemblage of several species $[35,72]$. Indeed, $C$. ovatum has been recorded from the gall bladder of 9 species of sharks and rays from the Pacific coast of the USA, the Atlantic coast of Argentina and the Atlantic coast of Africa [44, 52, 54], and having such low host specificity and broad geographical area is rather unusual for myxozoans and casts doubts on the actual identity of its components, an issue requiring resolution.

Due to the poorly detailed description available for C. multicostatum, that precludes its discrimination from congeners, as well as to the misidentification of the only host reported, this taxon is relegated to the status of a species inquirenda. Indeed, three species of elasmobranch genus Squatina inhabit the Atlantic coast of Argentina, S. argentina (Marini), S. guggenheim Marini and S. occulta Vooren and Da Silva [60], therefore it is not possible to identify which species was misidentified as $S$. squatina by Kuznetsova [54].

Certainly, future implementation of molecular approaches and morphological revision of Chloromyxum species reported in chondrichthyan from the Argentine Sea by Kuznetsova [54] will undoubtedly lead to reassessments (including redescriptions) of these taxa and further resolution of possible cryptic species. 
The advent of PCR methods and readily accessible DNA sequencing technologies have advanced our general understanding of myxozoan phylogenetic relationships and taxonomy. In particular, the SSU rDNA sequence has become an integral part of myxozoan species descriptions and phylogenetic studies. Despite the increasing number of available myxozoan SSU rDNA records in GenBank, the proportion of sequenced Chloromyxum species infecting the gall bladder of marine elasmobranch remains low. Indeed, the GenBank database provides information for only 10 (out of 25) elasmobranch-infecting Chloromyxum species (see Table 2).

Phylogenetic analyses have shown that primary myxosporean division is according to their host environment (either freshwater or marine realm) [28], with a third main group being the Sphaerospora sensu stricto clade from mixed environments [14, 46]. Clustering within these lineages appears to be related to the site of sporulation in the intermediate vertebrate host (coelozoic infecting the gall bladder, urinary bladder and kidney tubules or histozoic infecting muscles or other tissues) [41]. The Chloromyxum s.s clade uniting the marine gall bladder-infecting species is placed basally to the members of the freshwater myxosporean lineage [8, 13, 30, 35, 72], suggesting that the common ancestor of the freshwater myxosporean lineage was a parasite of the elasmobranchs [51]. In any event, as expected due to myxospore morphotype, host identity (elasmobranchs) and tissue infected (gall bladder), the three Chloromyxum species sequenced in this study occupy a position within the well-supported Chloromyxum s.s clade.

Although not without limitations and weaknesses (e.g. Long-branch attraction artefact [15]), the SSU rRNA gene has repeatedly proved to be sufficiently informative to estimate the phylogenetic relationships among myxozoans at different taxonomic levels [31]. However, single-gene analyses sometimes do not provide sufficient resolution for some nodes or sometimes give conflicting results. In fact, the species-level SSU rDNA phylogeny presented in this work could not be completely resolved, containing both well-supported and low-supported nodes. Indeed, while Chloromyxum parasites of Rajiformes from the South Atlantic Ocean (C. atlantoraji n. sp., $C$. zearaji n. sp. and $C$. riorajum) constituted a well-established monophyletic subclade with strong support for the three analytical methods used, nodes grouping the other Chloromyxum species, independently of the host taxonomic identities (Carchariniformes, Myliobatiformes, Orectolobiformes, Pristiophoriformes, Rajiformes, Squaliformes and Torpediniformes) and/or host range geographic distribution (Atlantic coast of Portugal, Atlantic coast of the USA, Australian waters or Mediterranean Sea), were poorly resolved or unresolved and, therefore, unclear.

The lack of resolution observed in the single-gene tree reconstruction presented in this work could be due to either artefacts of the inferences processes (analytical factors [15]), insufficient taxon sampling or may be biologically real. In an attempt to allow more accurate reconstructions with the current data set, different methodological approaches were implemented (results not shown), including variation in the stringency of removal of ambiguous characters of the input alignment and/or selection of different taxa as outgroup (i) taxa from a distant clade e.g. Kudoa carcharhini GU324970
+ Ceratomyxa carcharhini JF911815; (ii) a single taxon from the sister freshwater hepatic biliary clade e.g. Sphaeromyxa balbiani KF 135225; (iii) multiple taxa within the sister freshwater hepatic biliary clade e.g. S. balbiani KF135225 + Myxidium coryphaenoideum DQ377697 + Zschokkela nova DQ377690).In fact, none of these attempts overcame the lack of resolution and node instability observed.

Indeed, the difficulty in the phylogenetic reconstruction faced in the present work could be ascribed to the low amount of phylogenetic signal shown by the SSU rDNA molecular marker within the closely related Chloromyxum s.s. - e.g. speciation events closely spaced in time-. Acknowledging that it might not always be possible to obtain a fully-resolved and well-supported species tree $[10,43]$, further improvements of Chloromyxum s.s. phylogeny could be achieved by the inclusion of data from other loci - e.g. LSU rDNA and/or EF-2 gene $[13,29]$ - or by increase taxon sampling in order to strengthen the phylogenetic signal.

A phylogeny of a group of organisms has several determinants in the historical context for biogeography and ecology. Particularly, phylogenies of parasite taxa are structured and historically constrained by genealogical and ecological associations with their host (or hosts for parasites with complex life cycles) within the context of frameworks and hypotheses for co-evolution (encompassing co-speciation and co-adaptation) and historical biogeography across varying temporal (evolutionary to ecological time) and spatial scales (local, regional to global) [38]. Though elucidating the processes and contingencies that structured the phylogenetic relationships among Chloromyxum s.s. species is beyond the scope of the present work, some clear macroevolutionary patterns were depicted from the tree topology inferred in synopsis with biological and ecological aspects of Chloromyxum species and their hosts.

Analysing data in the context of host identity-based structure, one of the most prominent results is the partial incongruence and inconsistence of phylogenies for the genus Chloromyxum and their elasmobranch intermediate hosts, with closely related hosts not harbouring closely related parasites. At least for those species parasitizing Rajiformes, the only well supported sublineage from the South West Atlantic Ocean, clearly do not encompass the other Chloromyxum species from Rajiformes included in the analyses (C. clavatum from the Atlantic coast of Portugal) that clustered separately. Of course, this pattern is not surprising as departures from strict co-speciation are frequently observed. Such lack of complete congruence could be a consequence of many macroevolutionary events from deep evolutionary to shallow ecological timeframes (e.g. host switching, sorting or extinction, geographical dispersal, duplication or intrahost speciation, inertia or lack of parasite speciation, colonization, etc.) $[9,17,39,68]$.

In phylogeny-based approaches, hierarchical order over spatial and temporal scales constrains the range of explanations for understanding patterns that have driven diversification in evolutionary and biogeographic history [37,38]. As a generality in host-parasite assemblages, geographic scale may be linked to the relative age of the host-parasite association and to the duration of their co-evolutionary history [38]. In this sense, the global distribution of the members of the genus Chloromyxum may be indicative of an old association with their 
specific host group (elasmobranchs), as it is proven for other groups of parasites $[16,17,21,40]$. The same is true at a smaller geographic scale for chloromyxids found infecting south Atlantic skates, whose association could not pre-date Early Cretaceous times when the South Atlantic Ocean originated [23]. Estimating divergence time from molecular sequence data for Chloromyxum species and their hosts could further contribute to address the relative age of these associations.

It is noteworthy that the only well-supported subclade of Chloromyxum species is composed of sympatric members. Therefore, it is reasonable to infer that the cladogenesis of these species may be the result of a colonization event followed by local isolation and diversification, a process requiring further analyses considering the geographical and temporal bounds of this particular ecological zone. Globally, the Southwestern Atlantic Ocean has one of the highest degrees of endemism in skates [24, 32] with the genera Rioraja (Whitley) and Atlantoraja (Menni) being endemic [24, 32]. On the other hand, Zearaja (Whitley) is a cosmopolitan genus; however, Z. chilensis is restricted to the South American shelf, inhabiting Atlantic and Pacific waters [61]. The isolation of this habitat maintained over evolutionary time may have contributed to increase the diversity of endemic hosts and parasites through coevolutionary processes. In fact, it is proven that areas of high host endemism are also areas of parasite endemism [67]. Molecular analyses, including of new Chloromyxum species from elasmobranchs belonging to different families and orders from the South Atlantic Ocean, will allow us to assess the evolution of these geographical lineages.

Acknowledgments. Thanks are extended to Mr. Miguel Fittipaldi and Mr Atilio Altamiranda from El Corsario Fishing Company for providing fish samples; to Dr Santiago A. Barbini (Instituto de Investigaciones Marinas y Costeras - Consejo Nacional de Investigaciones Científicas y Técnicas) and Lic. David Sabadin (Instituto de Investigaciones Marinas y Costeras - Consejo Nacional de Investigaciones Científicas y Técnicas) for helping in the identification of skates. Financial support was provided by grants from Consejo Nacional de Investigaciones Científicas y Técnicas (PIP 2015-2017 112-201501-00973); Fondo para la Investigación Científica y Tecnológica (PICT \#2015-2013 and PICT\#2016-0450) and Universidad Nacional de Mar del Plata (EXA 869/16). Funding for molecular analysis was provided by the Czech Science Foundation, project numbers 505/12/G112 and 16-20744S.

\section{Conflict of interest}

The authors declare that they have no conflict of interest.

\section{References}

1. Anderson MJ. 2001. A new method for non-parametric multivariate analysis of variance. Austral Ecology, 26, 32-46.

2. Anderson MJ, Robinson J. 2003. Generalized discriminant analysis based on distances. Australian \& New Zealand Journal of Statistics, 45, 301-318.

3. Anderson MJ, Willis TJ. 2003. Canonical analysis of principal coordinates: a useful method of constrained ordination for ecology. Ecology, 84, 511-525.
4. Anderson MJ, Gorley RN, Clarke KR. 2008. PERMANOVA + for PRIMER: Guide to Software and Statistical Methods. PRIMER-E Ltd.: Plymouth.

5. Asahida T, Kobayashi T, Saitoh K, Nakayama I. 1996. Tissue preservation and total DNA extraction from fish stored at ambient temperature using buffers containing high concentration of urea. Fisheries Science, 62, 727-730.

6. Atkinson SD, Bartošová-Sojková P, Whipps CM, Bartholomew JL. 2015. Approaches for characterising Myxozoan species, in Myxozoan evolution, ecology and development. Okamura B, Gruhl A, Bartholomew JL, Editors. Springer: London. p. 111-123.

7. Awerinzew S. 1913. Ergebnisse der Intersuchungen über parasitische Protozoen der tropischen Region Afrikas. Zoologischer Anzeiger, 42, 151-156.

8. Azevedo C, Casal G, García P, Matos P, Teles-Grilo L, Matos E. 2009. Ultrastructural and phylogenetic data of Chloromyxum riorajum sp. nov. (Myxozoa), a parasite of the stingray Rioraja agassizii in Southern Brazil. Diseases of Aquatic Organisms, $85,41-51$.

9. Barker SC. 1991. Evolution of host-parasite associations among species of lice and rock wallabies: coevolution? International Journal for Parasitology, 21, 497-501.

10. Barraclough TG, Nee S. 2001. Phylogenetics and speciation. Trends in Ecology \& Evolution, 16, 391-399.

11. Barta JR, Martin DS, Liberator PA, Dashkevicz M, Anderson JW, Feighner SD, Elbrecht A, Perkins-Barrow A, Jenkins MC, Danforth HD, Ruff MD, Profous-Juchelka H. 1997. Phylogenetic relationship among eight Eimeria species infecting domestic fowl inferred using complete small subunit ribosomal DNA sequences. Journal of Parasitology, 83, 262-271.

12. Bartošová P, Fiala I. 2011. Molecular evidence for the existence of cryptic species assemblages of several myxosporeans (Myxozoa). Parasitology Research, 108, 573-583.

13. Bartošová P, Fiala I, Hypša V. 2009. Concatened SSU and LSU rDNA data confirm the main evolutionary trends within myxosporeans (Myxozoa: Myxozporea) and provide an effective tool for their molecular phylogenetics. Molecular Phylogenetics and Evolution, 53, 81-93.

14. Bartošová P, Fiala I, Jirků M, Cinková M, Caffara M, Fioravanti ML, Atkinson SD, Bartholomew JL, Holzer AS. 2013. Sphaerospora sensu stricto: Taxonomy, diversity and evolution of a unique lineage of myxosporeans (Myxozoa). Molecular Phylogenetics and Evolution, 68, 93-105.

15. Bergsten J. 2005. A review of long-branch attraction. Cladistics, 21, 163-193.

16. Boeger WA, Kritsky DC. 1997. Coevolution of the Monogenoidea (Platyhelminthes) based on a revised hypothesis of parasite phylogeny. International Journal for Parasitology, 27, 1495-1511.

17. Brooks DR, McLennan DA. 1993. Parascript - Parasites and the language of evolution. Smithsonian Institution Press: Washington, DC.

18. Clarke KR, Gorley RN. 2015. PRIMER v7: User Manual/ Tutorial. PRIMER-E Ltd.: Plymouth.

19. Clarke KR, Gorley RN, Somerfield PJ, Warwick RM. 2014. Change in marine communities. An approach to statistical analysis and interpretation. PRIMER-E Ltd.: Plymouth.

20. Colonello JH, Cortés F, Massa AM. 2014. Species richness and reproductive modes of chondrichthyans in relation to temperature and fishing effort in the Southwestern Atlantic Shelf (34-54ㅇ S). Fisheries Research, 160, 8-17.

21. Cribb TH, Bray RA, Littlewood DTJ. 2001. The nature and evolution of the association among digeneans, molluscs and fishes. International Journal for Parasitology, 31, 997-1011. 
22. Díaz de Astarloa JM, Mabragaña E, Hanner E, Figueroa DE. 2008. Morphological and molecular evidence for a new species of longnose skate (Rajiformes: Rajidae: Dipturus) from Argentinean waters based on DNA barcoding. Zootaxa, 1924, 35-46.

23. Eagles G. 2007. New angles on south Atlantic opening. Geophysical Journal International, 168, 353-361.

24. Ebert DA, Compagno LJV. 2007. Biodiversity and systematic of skates (Chondrichthyes: Rajiformes: Rajoidei). Environmental Biology of Fishes, 80, 111-124.

25. Eiras JC, Lu YS, Gibson DI, Fiala I, Saraiva A, Cruz C, Santos MJ. 2012. Synopsis of the species Chloromyxum Mingazinni, 1890 (Myxozoa: Myxosporea: Chloromyxidae). Systematic Parasitology, 83, 203-225.

26. Eschmeyer WN, Fricke R, van der Laan R. 2016. Catalog of fishes: genera, species, references. http://researcharchive.calacademy.org/research/ichthyology/catalog/fishcatmain.asp. Accessed 1 August 2017.

27. Evdokimova EB. 1977. Myxosporidians of teleost fishes from the Patagonian shelf (The Atlantic Coast of Argentina). Parazitologiya, 11, 166-178.

28. Fiala I. 2006. The phylogeny of Myxosporea (Myxozoa) based on small subunit ribosomal RNA gene analysis. International Journal for Parasitology, 36, 1521-1534.

29. Fiala I, Bartošová P. 2010. History of myxozoan character evolution on the basis of rDNA and EF-2 data. BMC Evolutionary Biology, 10, 228.

30. Fiala I, Dyková I. 2004. The phylogeny of marine and freshwater species of the genus Chloromyxum Mingazzini, 1890 (Myxosporea: Bivalvulida) based on small subunit ribosomal RNA gene sequences. Folia Parasitologica, 51, 211-214.

31. Fiala I, Bartošová-Sojková P, Whipps CM. 2015. Classification and phylogenetics of Myxozoa, in Myxozoan evolution, ecology and development. Okamura B, Gruhl A, Bartholomew JL, Editors. Springer: London. p. 85-110.

32. Figueroa DE, Barbini S, Scenna L, Belleggia M, Delpiani G, Spath C. 2013. El endemismo en las rayas de la Zona Común de Pesca Argentino-Uruguaya. Frente Marítimo, 23, 95-104.

33. Froese R, Pauly D. 2016. FishBase. World Wide Web electronic publication. http://fishbase.org. Accessed 1 August 2017.

34. Gioia I, Cordeiro NS. 1996. Brazilian myxosporidians' checklist (Myxozoa). Acta Protozoologica, 35, 137-149.

35. Gleeson RJ, Adlard RD. 2012. Phylogenetic relationship amongst Chloromyxum Mingazzini, 1890 (Myxozoa: Myxosporea), and the description of six novel species from Australian elasmobranchs. Parasitology International, 61, 267-274.

36. Hallet SL, Diamant A. 2001. Ultrastructure and small-subunit ribosomal DNA sequence of Henneguya lesteri n. sp. (Myxosporea), a parasite of sand whiting Sillago analis (Sillaginidae) from the coast of Queensland, Australia. Diseases of Aquatic Organisms, 46, 197-212.

37. Hoberg EP, Brooks DR. 2008. A macroevolutionary mosaic: episodic host-switching, geographical colonization and diversification in complex host-parasite systems. Journal of Biogeography, 35, 1533-1550.

38. Hoberg EP, Klassen GJ. 2002. Revealing the faunal tapestry: co-evolution and historical biogeography of hosts and parasites in marine systems. Parasitology, 124, S3-S22.

39. Hoberg EP, Brooks DR, Siegel-Causey D. 1997. Host-parasite cospeciation: history, principles and prospects, in Hostparasite evolution: General principles and avian models. Clayton DH, Moore J, Editors. Oxford University Press: Oxford. p. 212-235.
40. Hoberg EP, Gardner SL, Campbell RA. 1999. Systematics of the Eucestoda: advances toward a new phylogenetic paradigm, and observations on the early diversification of tapeworms and vertebrates. Systematic Parasitology, 42, 1-12.

41. Holzer AS, Sommerville C, Wootten R. 2004. Molecular relationships and phylogeny in a community of myxosporeans and actinosporeans based on their 18S rDNA sequences. International Journal for Parasitology, 34, 1099-1111.

42. Holzer AS, Wootten R, Sommerville C. 2010. Zschokkella hildae Auerbach, 1910: Phylogenetic position, morphology, and location in cultured Atlantic cod. Parasitology International, 59, 133-140.

43. Humphries EM, Winker K. 2010. Working through polytomies: Auklets revisited. Molecular Phylogenetics and Evolution, 54, 88-96.

44. Jameson AP. 1929. Myxosporidia from Californian fishes. Journal of Parasitology, 16, 59-68.

45. Jaureguizar AJ, Menni RC, Lasta CA, Guerrero RA. 2006. Fish assemblages of the northern Argentine coastal system: spatial patterns and their temporal variations. Fisheries Oceanography, $15,326-344$

46. Jirků M, Fiala I, Modrý D. 2007. Tracing the genus Sphaerospora: rediscovery, redescription and phylogeny of the Sphaerospora ranae (Morelle, 1929) n. comb. (Myxosporea, Sphaerosporidae), with emendation of the genus Sphaerospora. Parasitology, 134, 1727-1739.

47. Jirků M, Bartošová P, Kodádková A, Mutschmann F. 2011. Another chloromyxid lineage: molecular phylogeny and redescription of Chloromyxum careni from the Asian Horned frog Megophrys nasuta. Journal of Eukaryotic Microbiology, $58,50-59$.

48. Katoh K, Misawa K, Kuma K, Miyata T. 2002. MAFFT: a novel method for rapid multiple sequence alignment based on fast Fourier transform. Nucleic Acid Research, 30, 3059-3066.

49. Kent ML, Khattra J, Hervio DML, Devlin RH. 1998. Ribosomal DNA sequence analysis of isolates of the PKX myxosporean and their relationship to members of the genus Sphaerospora. Journal of Aquatic Animal Health, 10, 12-21.

50. Kent ML, Andree KB, Bartholomew JL, El-Matbouli M, Desser SS, Devlin RH, Feist SW, Hedrick RP, Hoffmann RW, Khattra J, Hallett SL, Lester RJG, Longshaw M, Palenzeula O, Siddall ME, Xiao C. 2001. Recent advances in our knowledge of the Myxozoa. Journal of Eukaryotic Microbiology, 48, 395-413.

51. Kodádková A, Bartošová-Sojková P, Holzer AS, Fiala I. 2015. Bipteria vetusta $\mathrm{n}$. sp. - an old parasite in an old host: tracing the origin of myxosporean parasitism in vertebrates. International Journal for Parasitology, 45, 269-276.

52. Kovaljova AA. 1988. Myxoporidia of the genus Chloromyxum (Cnidospora, Myxosporea) of cartilaginous fishes from the Atlantic coast of Africa. Parazitologiya, 22, 384-388.

53. Kudo RR. 1919. Studies on Myxosporidia. A synopsis on genera and species of Myxosporidia. Biological Monographs, $5,1-265$.

54. Kuznetsova IG. 1977. Myxosporidians of Chondrostei from the Patagonian shelf. Parazitologiya, 11, 74-77.

55. Lom J, Arthur JR. 1989. A guideline for the preparation of species descriptions in Myxosporea. Journal of Fish Diseases, $12,151-156$.

56. Lom J, Dyková I. 1992. Protozoan Parasites of Fishes. Developments in Aquaculture and Fisheries. Elsevier: Amsterdam.

57. Lom J, Dyková I. 2006. Myxozoan genera: definition and notes on taxonomy, life-cycle terminology and pathogenic species. Folia Parasitologica, 53, 1-36. 
58. Lucifora LO, García VB, Menni RC, Worm B. 2012. Spatial patterns in the diversity of sharks, rays, and chimaeras (Chondrichthyes) in the Southwest Atlantic. Biodiversity and Conservation, 21, 407-419.

59. Menni RC, López HL. 1984. Distributional patterns of Argentine marine fishes. Physis, 42, 71-85.

60. Menni RC, Lucífora LO. 2007. Condrictios de la Argentina y Uruguay. Lista de Trabajo. ProBiota, FCNyM, UNLP, Serie Técnica-Didactica, La Plata, Argentina, 11, 1-15.

61. Menni RC, Stehmann MF. 2000. Distribution, environment and biology of batoid fishes off Argentina, Uruguay and Brazil. A review. Revista del Musea Argentino de Ciencias Naturales (Argentina), 2, 69-109.

62. Menni RC, Rincón G, García ML. 2008. Discopyge castelloi sp. nov. (Torpediniformes, Narcinidae), una nueva especie de raya eléctrica del Mar Argentina. Revista del Musea Argentino de Ciencias Naturales (Argentina), 10, 161-171.

63. Menni RC, Jaureguizar AJ, Stehmann MFW, Lucifora LO. 2010. Marine biodiversity at the community level: zoogeography of sharks, skates, rays and chimaeras in the Southwestern Atlantic. Biodiversity and Conservation, 19, 775-796.

64. Mingazzini P. 1890. Sullo sviluppo dei Myxosporidi. Bollettino della Società di Naturalisti, 4, 160-164.

65. Molnár K. 1994. Comments on the host, organ and tissue specificity of fish myxosporeans and on the types of their intrapiscine development. Parasitologica Hungarica, 27, 5-20.

66. Molnár K, Eszterbauer E. 2015. Specificity of infection sites in vertebrate hosts, in Myxozoan evolution, ecology and development. Okamura B, Gruhl A, Bartholomew JL, Editors. Springer: London. p. 295-313.

67. Morand S, Guégan J-F. 2000. Patterns of endemism in hostparasite associations: lessons from epidemiological models and comparative test. Belgian Journal of Entomology, 2, 135-147.

68. Paterson AM, Banks J. 2001. Analytical approaches to measuring co-speciation of host and parasites: through the glass darkly. International Journal for Parasitology, 31, 1012-1022.

69. Pinto C. 1928. Mixosporídeos e outros protozoários intestinais observados na América do Sul. Archivos do Instituto Biológico, 1, 101-102.
70. Rambaut ADrummond AJTracer v1.42007 http://beast.bio.ed.ac.uk/Tracer

71. Rocha S, Azevedo C. 2012. Light and electron microscopy applied to the characterization of marine species belonging to the genus Chloromyxum, as a study model for myxosporean parasites, in Current Microscopy Contributions to Advances in Science and Technology, Méndez-Vilas A, Editor. Formatex Research Center: Badajoz, p. 471-477.

72. Rocha S, Casal G, Al-Quraishy S, Azevedo C. 2013. Morphological and molecular characterization of a new myxozoan species (Myxosporea) infecting the gall bladder of Raja clavata (Chondrichthyes), from the Portuguese Atlantic Coast. Journal of Parasitology, 99, 307-317.

73. Rocha S, Casal G, Al-Quraishy S, Azevedo C. 2014. Morphological and ultrastructural redescription of Chloromyxum leydigi Mingazzini, 1890 (Myxozoa: Myxosporea), type species of the genus, infecting the gall bladder of the marine cartilaginous fish Torpedo marmorata Risso (Chondrichthyes: Torpedinidae), from the Portuguese Atlantic coast. Folia Parasitologica, 61, 110.

74. Ronquist F, Huelsenbeck JP. 2003. MrBayes 3: Bayesian phylogenetic inference under mixed models. Bioinformatics, $19,1572-1574$.

75. Ruocco NL, Lucifora LO, Díaz de Astarloa JM, Mabragaña EM, Delpiani MS. 2012. Morphology and DNA barcoding reveal a new species of eagle ray from the Southwestern Atlantic: Myliobatis ridens sp. nov. (Chondrichthyes: Myliobatiformes: Myliobatidae). Zoological Studies, 51, 863873.

76. Schneider CA, Rasband WS, Eliceiri KW. 2012. NIH Image to ImageJ: 25 years of image analysis. Nature Methods, 9, 671-675.

77. Stamatakis A. 2006. RAxML-VI-HPC: maximum likelihoodbased phylogenetic analyses with thousands of taxa and mixed models. Bioinformatics, 22, 2688-2690.

78. Swofford DL. 2003. PAUP*: Phylogenetic Analysis Using Parsimony (*and other methods). Version 4. Sinauer Associates, Sunderland, Massachusetts.

Cite this article as: Cantatore DMP, Irigoitia MM, Holzer AS, Bartošová-Sojková P, Pecková H, Fiala I \& Timi JT. 2018. The description of two new species of Chloromyxum from skates in the Argentine Sea reveals that a limited geographic host distribution causes phylogenetic lineage separation of myxozoans in Chondrichthyes. Parasite 25, 47.

Reviews, articles and short notes may be submitted. Fields include, but are not limited to: general, medical and veterinary parasitology; morphology, including ultrastructure; parasite systematics, including entomology, acarology, helminthology and protistology, and molecular analyses; molecular biology and biochemistry; immunology of parasitic diseases; host-parasite relationships; ecology and life history of parasites; epidemiology; therapeutics; new diagnostic tools.

All papers in Parasite are published in English. Manuscripts should have a broad interest and must not have been published or submitted elsewhere. No limit is imposed on the length of manuscripts.

Parasite (open-access) continues Parasite (print and online editions, 1994-2012) and Annales de Parasitologie Humaine et Comparée (1923-1993) and is the official journal of the Société Française de Parasitologie. 